\title{
The Effect of Customer-to-Customer Interactions on the Preference of Fashion Purchase Environment
}

\author{
Ihn Hee Chung ${ }^{\dagger}$ \\ Dept. of Materials Design Engineering, Kumoh National Institute of Technology \\ Received November 21, 2011; Revised December 9, 2011; Accepted December 16, 2011
}

\begin{abstract}
This study identifies the effect of customer-to-customer interactions on the preference of fashion purchase environment. An empirical study surveyed male and female consumers 25 years of age and older in Daegu, Korea, in August 2011. A total of 338 responses were analyzed using descriptive statistics and chi-square analysis of SPSS 19.0. The results identified the effects of the number, gender, age, attractiveness, and taste of other customers in fashion retail settings. In addition, differences in the effect of customer-to-customer interactions according to consumer attributes were also verified. The sample of this study preferred a shopping condition of many shoppers in the store, the same gender shoppers in the store, the same aged shoppers in the store, an attractive shopper in the store, and a shopper having the same taste in the store. Female consumers showed a preference for a store environment with many shoppers and the same gender shoppers to a store of no shoppers and different gender shoppers compared to male consumers. Aged consumers and fashion-involved consumers liked to shop with more attractive persons than less attractive persons. Fashion-innovative consumers wanted to enter a store where the other customers have similar tastes.
\end{abstract}

Key words: Customer-to-customer interactions, Fashion store, Purchase environment, Fashion innovativeness, Fashion involvement

\section{Introduction}

In the domain of services marketing, interactions between service provider and customer have been considered as critical elements of customer satisfaction with services and customer perception of service quality (Fisk et al., 1993; Solomon et al., 1985). The importance of other customers' role in service encounters, on the other hand, has been getting attention from services marketing and consumer behavior researchers. The service encounter is often characterized by the condition of diverse types of customers whose presence may influence each other (Grove \& Fisk, 1997).

The stream of researches on customer-to-customer

Corresponding author

E-mail: ihnhee@kumoh.ac.kr

This paper was supported by Research Fund, Kumoh National Institute of Technology. interaction could be divided into three directions. The first one is to investigate the types or levels of customerto-customer interactions in services setting (Huang \& Hsu, 2009, 2010; Parker \& Ward, 2000; Wu, 2008). The second one is to determine the list of public behaviors either making favorable/friendly impression or not (Grove \& Fisk, 1997; Martin, 1996; Wu, 2007, 2008). The last one is to examine the effect of customer density and homogeneity on the perception of service quality or satisfaction (Nicholls, 2011; Söderlund, 2011; $\mathrm{Wu}, 2007)$.

Zhang et al. (2010) provided the list of 15 typical service settings: air/train/bus, amusement park, bank, bar, concert, cruise, doctor/physician's office, hair salon/ barber shop, hotel/motel, grocery, gym, movie theater, retail store, restaurant, and sports game. A number of studies of customer-to-customer interaction have been conducted mainly in the tourism context, because tour- 
ism is a service industry where customers often interact with each other for extended period of time and in the high involvement context (Nicholls, 2011). Besides, studies regarding other service settings such as restaurants, sports center, and hair salons have been published (e.g. Martin, 1996; Moore et al., 2005).

Recently, Söderlund (2011) expanded the investigation of customer-to-customer interaction into the merchandise retail setting such as convenience store. Store environment and store image, in general, are regarded as controllable with lighting, temperature, scents, sound, product assortment, and visual merchandising. Some kinds of store environment are beyond control. Interpersonal interaction and the presence or absence of people in a store make up a temporarily new social surrounding.

Every product is offered along with services, thus they could be the research target of customer-to-customer interaction. Moreover, fashion is very self-expressive and emotional, therefore high involvement products, and studies concerning the fashion retail context would be valuable because of the complicated mutual process. The effect of customer-to-customer interaction in fashion marketing area is definitely an area of needed research, but, nonetheless, there is not a vestige of related studies in this field.

Fashion innovativeness might be one of the few variables that have an immediate relevance to consumer behaviors (Muzinich et al., 2003), and fashion involvement influences purchase behavior (Pentecost \& Andrews, 2010). Throughout widespread and cumulative empirical studies (Cardoso et al., 2010; Cho \& Workman, 2011; Goldsmith, 2002; Jun \& Rhee, 2009; Muzinich et al., 2003, etc.), it has been verified that the value of fashion innovativeness and fashion involvement are useful concepts explaining fashion consumer behaviors. These two variables with essential demographic variables should be first examined in relation to customer-tocustomer interaction, a newly introduced notion to this academic field.

The ultimate purpose of this study is to identify the possibility and the worth of research on customer-tocustomer interaction in the fashion marketing area. Simple operationalization of customer-to-customer interaction in retail setting was given to test the effects of customer-to-customer interactions on the preference of fashion purchase environment, and the difference of those effects according to consumer attributes.

\section{Literature Review}

\section{Conception of Customer-to-customer Interaction}

Interactions between human beings are omnipresent, inescapable, and highly interdependent (Martin, 1996). Turley and Milliman (2000) summarized human variables of shopping atmosphere as employee characteristics, employ uniforms, crowding, customer characteristics, and privacy. It was from the mid-1970s that service management theory started to adopt a perspective that a customers' perception of service could be affected by behavior of other customers (Nicholls, 2011). In retail environment, many service encounters with other customers occur, and customers may affect one another directly or indirectly, too.

Although Huang and Hsu (2010) defined customerto-customer interaction as the direct interaction between unacquainted customers encountered in the service context for a cruise experience research, it might be proper that customer-to-customer interaction possibly occurs indirectly and implicitly in retail setting. In reference to the indirect effect of customer-to-customer interaction, the effects of retail crowing on consumer behavior have been studied in part. Park (2003) examined the effects of perceived retail crowding on consumers' emotion and shopping behavior, which identified that spatial crowding perception affected non-pleasant emotion, in turn avoidance shopping behavior. Ji and Lee's (2005) findings showed that in-store crowding in family restaurant caused negative customer's emotion and affected intention to repurchase, word-of-mouth, and long-term stay intention in negative direction.

Söderlund (2011) examined the effect of the number of other customers, the visible consumption and purchasing activities of other customers, and brief interactions with other customers in restaurant, convenience store, and cinema settings. As results, attitude toward retailer was more positive (1) in restaurant almost full than the one almost empty, (2) in convenience store having other customers who are aspiration group than avoidance 
group, and (3) in cinema where other customers respect social norms than other customers violate social norms.

Regarding customer density, though Park (2003) and Ji and Lee (2005) concluded that perception of crowding had negative effect on purchase behavior, the finding of Söderlund (2011) was confirmed that the condition in which the customer was totally alone had a negative impact on the overall retailer evaluation. Since the experimental design of aspiration and avoidance group could be epitomized in the matter of taste, it could be said that customers of the same taste had positive effect on the evaluation of retailer. In addition, Söderlund (2011) suggested gender, age, and physical attractiveness effect were factors worth examining.

In fashion marketing area, it is difficult to find out a research focusing on customer-to-customer interaction. Considering the nature of fashion products as a tool of self-expression and image management, interactions between customers in fashion stores occur more frequently in an implicit mode. In fashion retail environment, customer density and other customers' attributes such as gender, age, attractiveness, and taste may influence on consumers' perception of retail store and their purchase behavior.

\section{Related Variables of Customer-to-customer Interactions}

Dependent variables affecting from customer-to-customer interactions are varied. Many researchers measured positive/negative service experiences, customer satisfaction/dissatisfaction, overall evaluation of retailer, etc. (Grove \& Fisk, 1997; Martin, 1996; Nicholls, 2011; Söderlund, 2011; Wu, 2007; Zhang et al., 2010) as the consequents of customer-to-customer interactions.

These variables are resultant one after experiencing something, meanwhile, it is possible to derive variables that determines a purchase in advance. In retail store context, especially, this approach will be helpful to give insights to marketers and retailers. Preference of fashion purchase environment was employed to this study, because preference determines conviction and purchase in 'hierarchy of effects model' developed by Lavidge and Steiner (1961). In retail store choice, preference of fashion purchase environment functions as anticipation of customer-to-customer interactions based on cumulative previous experiences.

With regard to the variables differentiating the effects of customer-to-customer interactions, demographic variables should be examined at first because of the novelty of this research topic in the current field. Demographic factors are the most fundamental elements to explain attitudes and behaviors of human beings (Chung, 2011).

Fashion innovativeness and fashion involvement also were selected as affecting variables on the perception of customer-to-customer interactions in fashion purchase environment. These two variables are very essential psychographic variables interpreting fashion consumers' behavior. Since innovativeness is defined as the degree to which a consumer is willing to adopt new ideas relatively earlier than others (Rogers, 1995), fashion innovativeness could be defined as the readiness to adopt a new style in fashion market. Fashion involvement is the motivated, aroused, or interested state for fashion (Rhee, 1991), and the consumer's perceived importance of fashion clothing (Cardoso et al., 2010).

It has been discovered the significant relations to various fashion attitudes and behaviors of fashion innovativeness and fashion involvement. Jun and Rhee (2009) confirmed the influence of fashion innovativenss on fashion adoption. Muzinich et al. (2003) investigated the causal relationship between fashion innovativeness and the use of evaluative criteria. Multichannel choice was influenced by fashion innovativeness (Cho \& Workman, 2011). Lim (2007) identified that fashion involvement had impact on information search and brand loyalty. Goldsmith (2002) reported that heavy users of fashion were more involved and innovative about clothing. Cardoso et al. (2010) utilized fashion innovativeness and involvement as criteria segmenting fashion market.

\section{Methods}

\section{Hypotheses}

From the process of literature review, the following hypotheses were developed.

$\mathrm{H}$ 1. There will be general preference of fashion 
purchase environment.

$\mathrm{H}$ 1-1. There will be general preference of fashion purchase environment in the aspect of number of other shoppers.

H 1-2. There will be general preference of fashion purchase environment in the aspect of gender of other shoppers.

H 1-3. There will be general preference of fashion purchase environment in the aspect of age of other shoppers.

H 1-4. There will be general preference of fashion purchase environment in the aspect of attractiveness of other shoppers.

H 1-5. There will be general preference of fashion purchase environment in the aspect of taste of other shoppers.

H 2. There will be difference in the preference of fashion purchase environment according to customer attributes.

H 2-1. There will be difference in the preference of fashion purchase environment according to gender of customer.

H 2-2. There will be difference in the preference of fashion purchase environment according to age of customer.

H 2-3. There will be difference in the preference of fashion purchase environment according to fashion innovativeness of customer.

H 2-4. There will be difference in the preference of fashion purchase environment according to fashion involvement of customer.

\section{Stimuli}

As stimuli to measure the preference of fashion purchase environment, text-based scenarios were developed. Though color slides or video-based scenarios, which were adopted in previous studies (Park, 2003; Raajpoot \& Sharma, 2006), could deliver the actual store atmosphere well, the most important strength of text-based scenario is systematic manipulation of variables and context (Söderlund, 2011). One common scenario and a total of ten scenario options were developed in the present study. Considering the quantity of needed scenarios to examine the hypotheses, one common shopping context was given: "Imagine that you shop in the department store to purchase a formal suit. Just you find a nice suit from many displayed merchandises. Which side do you prefer to enter the store and examine, try, and purchase the suit between following paired conditions?" The setting of purchasing a formal suit in the department store was selected because of its universal characteristic. And, simplified optional conditions were applied to the five paired stimulant scenarios (e.g. "the condition that nobody except myself in the store is" vs. "the condition that many shoppers are in the store"). Five paired scenarios options were about number, gender, age, attractiveness, and taste of other shoppers.

\section{Measurements}

A survey instrument was developed, which consisted of measurements for preference of fashion purchase environment, fashion innovativeness, fashion involvement, and several demographic variables. Preference of fashion purchase environment comprises five dichotomous questions asking respondents to select one preferred scenario option to the other. Fashion innovativeness was measured by nine items adopted from Kim (2000) and Rhee (1991) with five-point Likert-type scale ( $1=$ strongly disagree, $3=$ neutral, $5=$ strongly agree). Fashion involvement was measured by five selected items from Zaichkowsky's (1985) PII (Personal Involvement Inventory), which were regarded as representative ones concerning their means and standard deviations in previous study (Chung et al., 2005). 'Trivial vs. fundamental', 'means nothing to me vs. means a lot to me', 'unexciting vs. exciting', 'unappealing vs. appealing', and 'worthless vs. valuable' were them. Seven-point semantic differential technique was applied to fashion involvement measurement. Demographic variables were gender, age, education, and income.

\section{Data Collection and Analysis}

Population of this empirical study was male and female adults residing in Daegu, Korea, and convenience sampling was used to collect research data. A survey 
involving male and female consumers 25 years of age and older was conducted at several public places such as railroad station, high street, etc. during August 2011. With the exclusion of incomplete ones, a total of 338 responses were analyzed using descriptive statistics and chi-square analysis of SPSS 19.0.

\section{Sample Characteristics}

Sample characteristic of this study was reported in $<$ Table 1>. Male subjects were $143(42.3 \%)$ and female subjects were 195 (57.7\%). Majority of subjects were in their late twenties, even though the age range of respondents was from 25 to 41 . The age average was 29.2. Most of the subjects (79.3\%) had college education experiences, and $35.2 \%$ of respondents reported their monthly income is between 2 million and 3 million Korean won.

\section{Results and Discussion}

\section{Effect on Customer-to-customer Interactions on the Preference of Fashion Purchase En- vironment}

Five one-variable chi square analyses were conducted to test Hypothesis 1 . As the following results, hypothesis 1 was accepted.

\section{1) Number Effect}

The result of chi-square analysis to test the effect of the number of other customers on the preference of fashion purchase environment was as shown in $<$ Table $2>$. The sample of this study preferred the shopping context of many shoppers in the store to that of nobody except themselves in the store significantly $(p<.05)$. This result corresponds to the findings of Söderlund (2011).

\section{2) Gender Effect}

The result of chi-square analysis to test the effect of the gender of other customer on the preference of fashion purchase environment was presented in $\langle$ Table $3>$. The sample of this study preferred the shopping context of the same gender shoppers in the store to that of different gender shoppers in the store significantly $(p<.05)$.

\section{3) Age Effect}

The result of chi-square analysis to test the effect of

Table 2. The number effect of other customers on the fashion purchase environment preference

\begin{tabular}{c|c|c}
\hline \hline Scenario & Frequency & Chi-square (prob.) \\
\hline $\begin{array}{c}\text { Nobody except oneself } \\
\text { in the store }\end{array}$ & 114 & \multirow{2}{*}{$35.799(.000)$} \\
\cline { 1 - 2 } Many shoppers in the store & 224 & \\
\hline
\end{tabular}

Table 3. The gender effect of other customers on the fashion purchase environment preference

\begin{tabular}{c|c|c}
\hline \hline Scenario & Frequency & Chi-square (prob.) \\
\hline The same gender shoppers & 287 & \multirow{2}{*}{$164.781(.000)$} \\
\cline { 1 - 2 } Different gender shoppers & 51 & \\
\hline
\end{tabular}

Table 1. Sample characteristics

\begin{tabular}{|c|c|c|c|c|c|c|c|c|}
\hline Variable & \multicolumn{8}{|c|}{ Frequency $(\%)$} \\
\hline \multirow{2}{*}{ Gender } & \multicolumn{4}{|c|}{ Male } & \multicolumn{4}{|c|}{ Female } \\
\hline & \multicolumn{4}{|c|}{$143(42.3 \%)$} & \multicolumn{4}{|c|}{$195(57.7 \%)$} \\
\hline \multirow{2}{*}{$\begin{array}{c}\text { Age } \\
(\text { average }=29.2)\end{array}$} & \multicolumn{4}{|c|}{$25-29$} & \multicolumn{4}{|c|}{$30-41$} \\
\hline & \multicolumn{4}{|c|}{$216(63.9 \%)$} & \multicolumn{4}{|c|}{$122(36.1 \%)$} \\
\hline \multirow[t]{2}{*}{ Education } & $\begin{array}{c}\text { Primary School } \\
\text { Experience }\end{array}$ & \multicolumn{2}{|c|}{$\begin{array}{c}\text { Middle School } \\
\text { Experience }\end{array}$} & \multicolumn{2}{|c|}{$\begin{array}{l}\text { High School } \\
\text { Experience }\end{array}$} & \multicolumn{2}{|c|}{ College Experience } & $\begin{array}{c}\text { Higher than } \\
\text { Graduate School }\end{array}$ \\
\hline & $2(0.6 \%)$ & \multicolumn{2}{|c|}{$2(0.6 \%)$} & \multicolumn{2}{|c|}{$36(10.7 \%)$} & & $(79.3 \%)$ & $30(8.9 \%)$ \\
\hline \multirow{2}{*}{$\begin{array}{l}\text { Monthly } \\
\text { Income }\end{array}$} & Less than $1000^{*}$ & $1000-2000$ & \multicolumn{2}{|c|}{$2000-3000$} & \multicolumn{2}{|c|}{$3000-4000$} & $4000-5000$ & More than 5000 \\
\hline & $62(18.37 \%)$ & $91(26.9 \%)$ & \multicolumn{2}{|c|}{$119(35.2 \%)$} & \multicolumn{2}{|c|}{$39(11.5 \%)$} & $13(3.8 \%)$ & $14(4.1 \%)$ \\
\hline
\end{tabular}

*Thousand Korean won 
the age of other customer on the preference of fashion purchase environment was presented in $<$ Table $4>$. The sample of this study preferred the shopping context of the same aged shoppers in the store to that of different aged shoppers in the store significantly $(p<.05)$.

\section{4) Attractiveness Effect}

The result of chi-square analysis to test the effect of the attractiveness of other customer on the preference of fashion purchase environment was shown in $\langle$ Table 5 $\rangle$. The sample of this study preferred the shopping context of a shopper more attractive than themselves to that of a shopper less attractive than themselves in the store significantly $(p<.05)$.

\section{5) Taste Effect}

The result of chi-square analysis to test the effect of the taste of other customer on the preference of fashion purchase environment was presented in $\langle$ Table 6$\rangle$. The sample of this study preferred the shopping context of a shopper trying on clothes in one's taste to that of a shopper trying on clothes not in one's taste significantly $(p<.05)$.

Table 4. The age effect of other customers on the fashion purchase environment preference

\begin{tabular}{c|c|c}
\hline \hline Scenario & Frequency & Chi-square (prob.) \\
\hline The same aged shoppers & 279 & \multirow{2}{*}{$143.195(.000)$} \\
\hline Different aged shoppers & 59 & \\
\hline
\end{tabular}

Table 5. The attractiveness effect of other customer on the fashion purchase environment preference

\begin{tabular}{c|c|c}
\hline \hline Scenario & Frequency & Chi-square (prob.) \\
\hline $\begin{array}{c}\text { Only one shopper less } \\
\text { attractive than oneself }\end{array}$ & 147 & \multirow{2}{*}{$5.728(.017)$} \\
\hline $\begin{array}{c}\text { Only one shopper more } \\
\text { attractive than oneself }\end{array}$ & 191 & \\
\hline
\end{tabular}

Table 6. The taste effect of other customer on the fashion purchase environment preference

\begin{tabular}{c|c|c}
\hline \hline Scenario & Frequency & Chi-square (prob.) \\
\hline $\begin{array}{c}\text { Only one shopper trying on } \\
\text { clothes of similar taste }\end{array}$ & 238 & $56.343(.000)$ \\
\cline { 1 - 2 } $\begin{array}{c}\text { Only one shopper trying on } \\
\text { clothes of dissimilar taste }\end{array}$ & 100 & \\
\hline
\end{tabular}

\section{Differences in the Effect of Customer-to- customer Interactions according to Consumer Attributes}

Four sets of a series of five chi-square analyses were conducted to test Hypothesis 2. As the following results, hypothesis 2 was accepted.

\section{1) Gender Differences in the Effect of Customer- to-customer Interactions}

According to gender, two effects of customer-tocustomer interaction were identified significantly $(p<$ $.05)$ : number effect and gender effect, as shown in $<$ Table $7>$. Female consumers $(\mathrm{n}=195)$ showed preference for a store environment in which many shoppers compared to male consumers ( $\mathrm{n}=143$ ). Female consumers more liked to shop with the shoppers of the same gender than those of the opposite gender compared to male consumers.

\section{2) Age Differences in the Effect of Customer-to- customer Interactions}

Two age groups were determined to test the age difference in the effect of customer-to-customer interaction. Considering the average age (29.2), subjects in their twenties were coded as low age group $(n=216)$, and subjects aged 30 and over were coded as high age group $(\mathrm{n}=122)$. According to age, one effect of customer-to-customer interaction, the effect of attractiveness of other customer, was identified significantly $(p<.05)$ as shown in $\langle$ Table $8>$. High age group showed strong preference for a store environment in which only one shopper more attractive than oneself shopped to a store in which only one shopper less attractive than oneself compared to low age group.

\section{3) Fashion Innovativeness Differences in the Effect of Customer-to-customer Interactions}

Fashion innovativeness index was calculated as summated score of nine fashion innovativeness items measured in five-point scale. The reliability (Chronbach's alpha) of measurement was .83 , therefore the measurement was judged as reliable. The possible index range was from 5 to 45, and the mean score was 29.1 (SD $=5.93$ ), which showed moderately high fashion innova- 
Table 7. The effects of customer-to-customer interaction according to the gender of consumers

\begin{tabular}{|c|c|c|c|c|}
\hline & \multirow{2}{*}{ Effect } & \multicolumn{2}{|c|}{$\begin{array}{c}\text { Frequency } \\
\text { (Expected Frequency) }\end{array}$} & \multirow{2}{*}{$\begin{array}{c}\text { Chi-square } \\
\text { (prob.) }\end{array}$} \\
\hline & & $\begin{array}{c}\text { Male } \\
(\mathrm{N}=143)\end{array}$ & $\begin{array}{l}\text { Female } \\
(\mathrm{N}=195)\end{array}$ & \\
\hline \multirow{2}{*}{ Number } & Nobody except oneself in the store & $\begin{array}{c}64 \\
(48.2)\end{array}$ & $\begin{array}{c}50 \\
(65.8)\end{array}$ & \multirow{2}{*}{$\begin{array}{l}13.485 \\
(.000)\end{array}$} \\
\hline & Many shoppers in the store & $\begin{array}{c}79 \\
(94.8)\end{array}$ & $\begin{array}{c}145 \\
(129.2)\end{array}$ & \\
\hline \multirow{2}{*}{ Gender } & The same gender shoppers & $\begin{array}{c}113 \\
(121.4)\end{array}$ & $\begin{array}{c}174 \\
(165.6)\end{array}$ & \multirow{2}{*}{$\begin{array}{l}6.712 \\
(.008)\end{array}$} \\
\hline & Different gender shoppers & $\begin{array}{c}30 \\
(21.6)\end{array}$ & $\begin{array}{c}21 \\
(29.4)\end{array}$ & \\
\hline \multirow{2}{*}{ Age } & The same age shoppers & $\begin{array}{c}114 \\
(118.0)\end{array}$ & $\begin{array}{c}165 \\
(161.0)\end{array}$ & \multirow{2}{*}{$\begin{array}{l}1.372 \\
(.152)\end{array}$} \\
\hline & Different age shoppers & $\begin{array}{c}29 \\
(25.0)\end{array}$ & $\begin{array}{c}30 \\
(34.0)\end{array}$ & \\
\hline \multirow{2}{*}{ Attractiveness } & Only one shopper less attractive than oneself & $\begin{array}{c}61 \\
(62.2)\end{array}$ & $\begin{array}{c}86 \\
(84.8)\end{array}$ & \multirow{2}{*}{$\begin{array}{l}.070 \\
(.439)\end{array}$} \\
\hline & Only one shopper more attractive than oneself & $\begin{array}{c}82 \\
(80.8)\end{array}$ & $\begin{array}{c}109 \\
(110.2)\end{array}$ & \\
\hline \multirow{2}{*}{ Taste } & Only one shopper trying on clothes of similar taste & $\begin{array}{c}99 \\
(100.7)\end{array}$ & $\begin{array}{c}139 \\
(137.3)\end{array}$ & \multirow{2}{*}{$\begin{array}{c}.167 \\
(.386)\end{array}$} \\
\hline & Only one shopper trying on clothes of dissimilar taste & $\begin{array}{c}44 \\
(42.3)\end{array}$ & $\begin{array}{c}56 \\
(57.7)\end{array}$ & \\
\hline
\end{tabular}

Table 8. The effects of customer-to-customer interaction according to the age of consumers

\begin{tabular}{|c|c|c|c|c|}
\hline & \multirow{2}{*}{ Effect } & \multicolumn{2}{|c|}{$\begin{array}{c}\text { Frequency } \\
\text { (Expected Frequency) }\end{array}$} & \multirow{2}{*}{$\begin{array}{c}\text { Chi-square } \\
\text { (prob.) }\end{array}$} \\
\hline & & $\begin{array}{l}\text { Low age } \\
(\mathrm{N}=216)\end{array}$ & $\begin{array}{l}\text { High age } \\
(\mathrm{N}=122)\end{array}$ & \\
\hline \multirow{2}{*}{ Number } & Nobody except oneself in the store & $\begin{array}{c}73 \\
(72.9) \\
\end{array}$ & $\begin{array}{c}41 \\
(41.1) \\
\end{array}$ & \multirow{2}{*}{$\begin{array}{c}.001 \\
(.535)\end{array}$} \\
\hline & Many shoppers in the store & $\begin{array}{c}143 \\
(143.1)\end{array}$ & $\begin{array}{c}81 \\
(80.9)\end{array}$ & \\
\hline \multirow{2}{*}{ Gender } & The same gender shoppers & $\begin{array}{c}182 \\
(183.4)\end{array}$ & $\begin{array}{c}105 \\
(103.6) \\
\end{array}$ & \multirow{2}{*}{$\begin{array}{c}.199 \\
(.391)\end{array}$} \\
\hline & Different gender shoppers & $\begin{array}{c}34 \\
(32.6)\end{array}$ & $\begin{array}{c}17 \\
(18.4)\end{array}$ & \\
\hline \multirow{2}{*}{ Age } & The same age shoppers & $\begin{array}{c}180 \\
(178.3)\end{array}$ & $\begin{array}{c}99 \\
(100.7)\end{array}$ & \multirow{2}{*}{$\begin{array}{c}.259 \\
(.357)\end{array}$} \\
\hline & Different age shoppers & $\begin{array}{c}36 \\
(37.7)\end{array}$ & $\begin{array}{c}23 \\
(21.3)\end{array}$ & \\
\hline \multirow{2}{*}{ Attractiveness } & Only one shopper less attractive than oneself & $\begin{array}{c}102 \\
(93.9)\end{array}$ & $\begin{array}{c}45 \\
(53.1)\end{array}$ & \multirow{2}{*}{$\begin{array}{l}3.390 \\
(.042)\end{array}$} \\
\hline & Only one shopper more attractive than oneself & $\begin{array}{c}114 \\
(122.1) \\
\end{array}$ & $\begin{array}{c}77 \\
(68.9) \\
\end{array}$ & \\
\hline \multirow{2}{*}{ Taste } & Only one shopper trying on clothes of similar taste & $\begin{array}{c}149 \\
(152.1) \\
\end{array}$ & $\begin{array}{c}89 \\
(85.9) \\
\end{array}$ & \multirow{2}{*}{$\begin{array}{c}.590 \\
(.261)\end{array}$} \\
\hline & Only one shopper trying on clothes of dissimilar taste & $\begin{array}{c}67 \\
(63.9)\end{array}$ & $\begin{array}{c}33 \\
(36.1)\end{array}$ & \\
\hline
\end{tabular}

tiveness of the sample. Two group of high $(\mathrm{n}=162)$ and low $(\mathrm{n}=176)$ fashion innovative groups were deter- mined based on the mean score. As shown in $\langle$ Table 9>, high fashion-innovative persons prefer a store with a 
Table 9. The effects of customer-to-customer interaction according to the fashion innovativeness of consumers

\begin{tabular}{|c|c|c|c|c|}
\hline & \multirow{2}{*}{ Effect } & \multicolumn{2}{|c|}{$\begin{array}{c}\text { Frequency } \\
\text { (Expected Frequency) }\end{array}$} & \multirow{2}{*}{$\begin{array}{l}\text { Chi-square } \\
\text { (prob.) }\end{array}$} \\
\hline & & $\begin{array}{l}\text { Low innovativeness } \\
(\mathrm{N}=176)\end{array}$ & $\begin{array}{l}\text { High innovativeness } \\
(\mathrm{N}=162)\end{array}$ & \\
\hline \multirow{2}{*}{ Number } & Nobody except oneself in the store & $\begin{array}{c}57 \\
(59.4) \\
\end{array}$ & \begin{tabular}{|c|}
57 \\
$(54.6)$ \\
\end{tabular} & \multirow{2}{*}{$\begin{array}{c}2.96 \\
(.334)\end{array}$} \\
\hline & Many shoppers in the store & $\begin{array}{c}119 \\
(116.6)\end{array}$ & $\begin{array}{c}105 \\
(107.4)\end{array}$ & \\
\hline \multirow{2}{*}{ Gender } & The same gender shoppers & $\begin{array}{c}150 \\
(149.4)\end{array}$ & $\begin{array}{c}137 \\
(137.6)\end{array}$ & \multirow{2}{*}{$\begin{array}{c}.029 \\
(.493)\end{array}$} \\
\hline & Different gender shoppers & $\begin{array}{c}26 \\
(26.6)\end{array}$ & $\begin{array}{c}25 \\
(24.4)\end{array}$ & \\
\hline \multirow{2}{*}{ Age } & The same age shoppers & $\begin{array}{c}142 \\
(145.3)\end{array}$ & $\begin{array}{c}137 \\
(133.7) \\
\end{array}$ & \multirow{2}{*}{$\begin{array}{c}.884 \\
(.213)\end{array}$} \\
\hline & Different age shoppers & $\begin{array}{c}34 \\
(30.7)\end{array}$ & $\begin{array}{c}25 \\
(28.3)\end{array}$ & \\
\hline \multirow{2}{*}{ Attractiveness } & Only one shopper less attractive than oneself & $\begin{array}{c}80 \\
(76.5) \\
\end{array}$ & $\begin{array}{c}67 \\
(70.5) \\
\end{array}$ & \multirow{2}{*}{$\begin{array}{l}.576 \\
(.258)\end{array}$} \\
\hline & Only one shopper more attractive than oneself & $\begin{array}{c}96 \\
(99.5) \\
\end{array}$ & $\begin{array}{c}95 \\
(91.5) \\
\end{array}$ & \\
\hline \multirow{2}{*}{ Taste } & Only one shopper trying on clothes of similar taste & $\begin{array}{c}113 \\
(123.9)\end{array}$ & $\begin{array}{c}125 \\
(114.1)\end{array}$ & \multirow{2}{*}{$\begin{array}{l}6.797 \\
(.006)\end{array}$} \\
\hline & Only one shopper trying on clothes of dissimilar taste & $\begin{array}{c}63 \\
(52.1)\end{array}$ & $\begin{array}{c}37 \\
(47.9)\end{array}$ & \\
\hline
\end{tabular}

customer trying on clothes in one's taste compared to low fashion-innovative persons significantly $(p<.05)$.

\section{4) Fashion Involvement Differences in the Effect of Customer-to-customer Interactions}

Fashion involvement index was calculated as summated score of five fashion involvement items. The reliability (Chronbach's alpha) of measurement was .86 , which meant the measurement was reliable. Fashion involvement index, measured in seven-point scale, might range from 7 to 35 . Mean of fashion involvement index was 26.8 ( $\mathrm{SD}=5.45$ ), a score revealing the sample's considerably high fashion involvement. The sample was divided into two groups, low $(\mathrm{n}=173)$ and high $(\mathrm{n}=165)$, based on the mean score. As shown in $\langle$ Table 10>, there was one significant effect of customer-to-customer interaction showing difference according to fashion involvement $(p<.05)$. High score group in fashion involvement expressed one's preference for a store in which an attractive shopper shopped, that they wanted to shop with attractive persons together. Reversely, Low fashion- involved group selected a store in which a shopper less attractive than oneself shopped a little more.

\section{Conclusions}

This study was designed in the aspect that fashion consumers would be affected from implied customerto-customer interaction in the fashion purchase settings because fashion has self-expressive and emotional nature. An empirical survey was conducted to identify the effect of customer-to-customer interactions on the preference of fashion purchase environment.

The findings regarding the effect of number, age, gender, attractiveness, and taste of other customers in the store were presented as statistically significant. The sample of this study preferred a shopping context of many shoppers in the store, the same gender shoppers in the store, the same aged shoppers in the store, an attractive shopper in the store, and a shopper having same taste in the store to those of the opposite conditions.

Differences in the effects of customer-to-customer 
Table 10. The effects of customer-to-customer interaction according to the fashion involvement of consumers

\begin{tabular}{|c|c|c|c|c|}
\hline & \multirow{2}{*}{ Effect } & \multicolumn{2}{|c|}{$\begin{array}{c}\text { Frequency } \\
\text { (Expected Frequency) }\end{array}$} & \multirow{2}{*}{$\begin{array}{l}\text { Chi-square } \\
\text { (prob.) }\end{array}$} \\
\hline & & $\begin{array}{l}\text { Low involvement } \\
\qquad(\mathrm{N}=173)\end{array}$ & $\begin{array}{l}\text { High involvement } \\
\qquad(N=165)\end{array}$ & \\
\hline \multirow{2}{*}{ Number } & Nobody except oneself in the store & $\begin{array}{c}61 \\
(58.3)\end{array}$ & $\begin{array}{c}53 \\
(55.7)\end{array}$ & \multirow{2}{*}{$\begin{array}{l}.372 \\
(.310)\end{array}$} \\
\hline & Many shoppers in the store & $\begin{array}{c}112 \\
(114.7)\end{array}$ & $\begin{array}{c}112 \\
(109.3)\end{array}$ & \\
\hline \multirow{2}{*}{ Gender } & The same gender shoppers & $\begin{array}{c}146 \\
(146.9)\end{array}$ & $\begin{array}{c}141 \\
(140.1)\end{array}$ & \multirow{2}{*}{$\begin{array}{l}.074 \\
(.452)\end{array}$} \\
\hline & different gender shoppers & $\begin{array}{c}27 \\
(26.1)\end{array}$ & $\begin{array}{c}24 \\
(24.9)\end{array}$ & \\
\hline \multirow{2}{*}{ Age } & The same age shoppers & $\begin{array}{c}140 \\
(142.8)\end{array}$ & $\begin{array}{c}139 \\
(136.2)\end{array}$ & \multirow{2}{*}{$\begin{array}{l}.645 \\
(.255)\end{array}$} \\
\hline & Different age shoppers & $\begin{array}{c}33 \\
(30.2)\end{array}$ & $\begin{array}{c}26 \\
(28.8)\end{array}$ & \\
\hline \multirow{2}{*}{ Attractiveness } & Only one shopper less attractive than oneself & $\begin{array}{c}89 \\
(75.2) \\
\end{array}$ & $\begin{array}{c}58 \\
(71.8) \\
\end{array}$ & \multirow{2}{*}{$\begin{array}{l}9.123 \\
(.002)\end{array}$} \\
\hline & Only one shopper more attractive than oneself & $\begin{array}{c}84 \\
(97.8)\end{array}$ & $\begin{array}{c}107 \\
(93.2)\end{array}$ & \\
\hline \multirow{2}{*}{ Taste } & Only one shopper trying on clothes of similar taste & $\begin{array}{c}119 \\
(121.8)\end{array}$ & $\begin{array}{c}119 \\
(116.2)\end{array}$ & \multirow{2}{*}{$\begin{array}{l}.451 \\
(.291)\end{array}$} \\
\hline & Only one shopper trying on clothes of dissimilar taste & $\begin{array}{c}54 \\
(51.2)\end{array}$ & $\begin{array}{c}46 \\
(48.8)\end{array}$ & \\
\hline
\end{tabular}

interactions according to consumer attributes were verified, too. Female consumers showed preference for a store environment of many shoppers and same gender shoppers compared to male consumers. Aged consumers and fashion-involved consumers liked to shop with more attractive persons to less attractive persons than themselves. Fashion-innovative consumers wanted to enter a store where the other customers having similar taste of themselves.

These results imply the importance of interpersonal effect on fashion retailing context. So far, the focus of interpersonal effect has given to the relationship between salesperson and customers from the viewpoint of customer relationship management (CRM). Now it needs to focus on customer-to-customer relationship and its role in fashion marketing. Other customers may have a profound impact upon the store perception as well as other store elements including salespersons and physical environment.

Along with the innovative development of information technology (IT), today's fashion purchase environment is changing drastically. With the increase of consumers' power, fashion companies are willing to depend on the new marketing tactics utilizing it, for example, virus marketing. It is possible to include the customer's comments and evaluations on merchandises of internet shopping malls as well as mouth-to-mouth communications into customer-to-customer interaction area, thus this topic of customer-to-customer interactions demands many further researches.

The present study was exploratory in nature, because customer-to-customer interaction was utterly a new research topic in fashion marketing area. Even though the research design and the measurement of this topic still need to be developed and refined, it was quite worthy of identifying the effects of customer-to-customer interactions on the preference of fashion purchase environment, and the difference of them according to consumer attributes. These findings accorded closely with the cumulative knowledge of customerto-customer interaction which tested in the other service settings, in the aspect of customer density, customer homogeneity, and association with a positive charge. 


\section{References}

Cardoso, P. R., Costa, H. S., \& Novais, L. A. (2010). Fashion consumer profiles in the Portuguese market: Involvement, innovativeness, self-expression and impulsiveness as segmentation criteria. International Journal of Consumer Studies, 34(6), 638-647.

Cho, S., \& Workman, J. (2011). Gender, fashion innovativeness and opinion leadership, and need for touch: Effects on multi-channel and touch/non-touch preference in clothing shopping. Journal of Fashion Marketing and Management, 15(3), 363-382.

Chung, I. H. (2011). Fashion marketing. Seoul: Sigongart.

Chung, I. H., Park. K. O., Lee, M. J., Min, K. S., \& Kang, J. K. (2005). A study on the job aptitudity of fashion salesperson. Journal of Distribution Research, 10(2), 73-97.

Fisk, R. P., Brown, S. W., \& Bitner, M. J. (1993). Tracking the evolution of the services marketing literature. Journal of Retailing, 69(1), 61-103.

Goldsmith, R. E. (2002). Some personality traits of frequent clothing buyers. Journal of Fashion Marketing and Management, 6(3), 303-316.

Grove, S. J., \& Fisk, R. P. (1997). The impact of other customers on service experiences: A critical incident examination of "getting along". Journal of Retailing, 73(1), 63-85.

Huang, J., \& Hsu, C. H. C. (2009). Interaction among fellow cruise passengers: Diverse experiences and impacts. Journal of Travel \& Tourism Marketing, 26(5-6), 547-567.

Huang, J., \& Hsu, C. H. C. (2010). The impact of customerto-customer interaction on cruise experience and vacation satisfaction. Journal of Travel Research, 49(1), 79-92.

Ji, S. G., \& Lee, S. G. (2005). The effect of in-store crowding on consumer emotions and behavioral intention. Journal of Korean Academy of Marketing Science, 15(3), 169-186.

Jun, D. G., \& Rhee, E. Y. (2009). The effects of fashion innovativeness and style-innovation attributes on fashion adoption. Journal of the Korean Society of Clothing and Textiles, 33(10), 1564-1574.

Kim, H. N. (2000). Consumer segmentation of clothing products by fashion conformity/innovativeness and their reference groups. Unpublished master's thesis, Seoul National University, Seoul.

Lavidge, R. J., \& Steiner, G. A. (1961). A model for predictive measurements of advertising effectiveness. Journal of Marketing, 25(October), 59-62.

Lim. K. B. (2007). The effect of clothing involvement and loyalty orientation on the information search behavior. Journal of the Korean Society of Clothing and Textiles, 31(9/10), 1396-1407.

Martin, C. L. (1996). Consumer-to-consumer relationships: Satisfaction with other consumers' public behaviors. The Journal of Consumer Affairs, 30(1), 146-169.
Moore, R., Moore, M. L., \& Capella, M. (2005). The impact of customer-to-customer interactions in a high personal contact service setting. Journal of Services Marketing, 19(7), 482-491.

Muzinich, N., Pecotich, A., \& Putrevu, S. (2003). A model of the antecedents and consequents of female fashion innovativeness. Journal of Retailing and Consumer Services, 10(5), 297-310.

Nicholls, R. (2011). Customer-to-customer interaction (CCI): A cross-cultural perspective. International Journal of Contemporary Hospitality Management, 23(2), 209-223.

Park, K. A. (2003). The effects of retail crowding on consumer emotions and shopping behaviors. Journal of the Korean Society of Clothing and Textiles, 27(2), 261-269.

Parker, C., \& Ward, P. (2000). An analysis of role adoptions and scripts during customer-to-customer encounters. European Journal of Marketing, 34(3/4), 341-358.

Pentecost, R., \& Andrews, L. (2010). Fashion retailing and the bottom line: The effects of generational cohorts, gender, fashion fanship, attitudes and impulse buying on fashion expenditure. Journal of Retailing and Consumer Services, 17(1), 43-52.

Raajpoot, N. A., \& Sharma, A. (2006). Perceptions of incompatibility in customer-to-customer interactions: Examining individual level differences. Journal of Services Marketing, 20(5), 324-332.

Rhee, Y. S. (1991). Consumer's clothing involvement and external information search. Unpublished doctoral dissertation, Seoul National University, Seoul.

Rogers, E. M. (1995). Diffusion of innovation (4th ed.). New York: The Free Press.

Söderlund, M. (2011). Other customers in the retail environment and their impact on the customer's evaluations of the retailer. Journal of Retailing and Consumer Services, 18(3), 174-182.

Solomon, M. R., Surprenant, C., Czepiel, J. A., \& Gutman, E. G. (1985). A role theory perspective on dyadic interactions: The service encounter. Journal of Marketing, 49(winter), 99-111.

Turley, L. W., \& Milliman, R. E. (2000). Atmospheric effects on shopping behavior: A review of the experimental evidence. Journal of Business Research, 49, 193-211.

$\mathrm{Wu}, \mathrm{C}$. H. J. (2007). The impact of customer-to-customer interaction and customer homogeneity on customer satisfaction in tourism service: The service encounter prospective. Tourism Management, 28(6), 1518-1528.

$\mathrm{Wu}, \mathrm{C}$. H. J. (2008). The influence of customer-to-customer interactions and role typology on customer reaction. The Service Industries Journal, 28(10), 1501-1513.

Zaichkowsky, J. L. (1985). Measuring the involvement construct. Journal of Consumer Research, 12(3), 341-252.

Zhang, J., Beatty, S. E., \& Mothersbaugh, D. (2010). A CIT investigation on other customers' influence in services. Journal of Services Marketing, 24(5), 389-399. 